\title{
Fod og takt
}

\section{Om Gerard Manley Hopkins og rytmen som lyrikkens musikalske element}

\author{
ThOMas TeILMANN DAMM
}

Music always had the freedom of prose with the intensity of verse; since Hopkins, English poetry has been able to enjoy liberty without laxity, on the analogy of music. This is why Hopkins is sometimes called 'the liberator'.

(Anthony Burgess) ${ }^{1}$

\section{I}

En del af det attraktive ved at tale om sprogets klang - og videre, tone - opstår vel ved den implicitte forudanelse om et mimetisk forhold: lyden mimer betydningen. I så fald baserer antagelser om et digts klangfarve sig på grader af onomatopoietikon eller melopoietikon; det sidste er Ezra Pounds betegnelse for „lydens emotionelle korrelat". Selv når det mimetiske forhold viser sig problematisk eller selvmodsigende, idet intet korrelat lader sig etablere uden hjælpekonstruktioner (hvorved klangen i sin umiddelbarhed intet betyder men vel nok kan give anledning til æstetisk hengivelse), øver forholdet indflydelse på læsningen. På dansk gives der eksempelvis umiddelbart et mimetisk forhold mellem ordene 'sort's og 'hvid's denotationer (nemlig de respektive farver) og deres klang. [Sort] klinger mørkt, [hvid(t)] klinger lyst og let. Til modeksempel denoterer det franske 'nuit' nat, men udtrykker i vokalens lys og konsonanternes relative lethed gennemsigtighed. Her kan vi altså tale om et misforhold, en bryd- 
ning i ordet selv. Hvad enten dette misforhold begrædes eller udnyttes af sprogbrugeren, viser det ham, så længe han er i forholdet og accepterer dets gyldighed, $\mathrm{i}$ en position, hvis grundlag netop er opfattelsen af et mimetisk forhold tegnets eller ordets sider imellem. ${ }^{2}$

Men man har i det hele taget sine problemer at slås med, når man ønsker at tale mere overordnet om sprogets klang eller tone. Begreberne her knytter jo straks en forbindelse til musikkens felt, og det ses ofte hævdet, at lyrikkens særlige status blandt anden litteratur skyldes dens tættere forhold til musikken. Digtet er traditionelt blevet opfattet som en musisk form. Det kan naturligvis henføres til simple forhold som den metrisk faste strofes sangbarhed, men indeholder også opfattelsen af, at digtet i klang og rytme - altså lydlige forhold - udtrykker en art førsproglighed og dermed noget, som er essentielt og oprindeligt. Det vil sige: lyrikken priviligeres gennem et andet (underforstået og på forhånd) priviligeret fænomen, musikken, som nemlig har status som oprindelig, naturlig, ægte og, hvilket for mig at se er omdrejningspunktet og i virkeligheden indeholdt i oprindelighedstænkningen, ikke-referentiel. Musikken afstår, på det primære niveau, fra at referere. Den mangler den denoterende funktion, der er sprogets; den er ren eksemplificering og ekspressivitet. Dette er i al fald den moderne, romantisk forstærkede musikforståelse. Til andre tider, $i$ antikken, i middelalderen, har man ikke tildelt musikken samme frie ekspressivitet. Men det vigtige er, at det er den musikforståelse man almindeligvis underforstår, når man taler om klang, tone og musik i sprog og digtning. Vi står altså med to forudsætninger: den, der er det mimetiske forhold mellem ordets lyd og dets betydning, og den, der sætter lyrikken i familie med musikken og læner sig til dens oprindelighed og. førsproglighed.

Men ofte ser man, hvordan vokabularet og dets viden begrænser forståelsen for det musiske i sproget. Naturligvis hører vi melodi i tale, men det vil normalt dreje sig om et stærkt begrænset tonespektrum. Jo større affekt, kan man sige, jo større spektrum, udsving; jo større, følger det, effekt. I digtet, hvad enten det læses højt eller 'hørt indenad', er det melodiske faktisk 
ofte undertrykt, undtagen hos særlige oplæsere, som så også afvises som netop affekterede. Endvidere forveksler man tale om melodi med tale om klang. Klangen er naturligvis begrænset af, at den oplæsende stemme kun er ét instrument, overtonesammensætningen varieres efter vokallydene. Såvel, som der til enhver tid er melodi i sprog, er der også klang, men hvis man henviser til et tilbagevendende mønster i tone eller klangfarve, er det jo netop et rytmisk fænomen, man dér beskriver. Ved at tale om lyrikkens særlige tone eller klang tilslører man, at også almindelig tale har melodi, og at vokal- og konsonant-lyde differentieres efter selve lydens sammensætning, der i sidste ende afhænger af instrumentets, det menneskelige organs, indstilling og beskaffenhed. Melodi og klang er derfor ikke indlysende hensigtsmæssige termer til identificering af det særligt lyriske, det må i al fald omformuleres eller præciseres til kun at gælde de forhold, hvor det påvirker liniens eller frasens substans. For det gælder, at selv rimet må opfattes (som funktion og morfologisk faktor, ikke som substans) som et rytmisk - om man vil - metrisk fænomen: Homofonien indtræder med mellemrum. ${ }^{3}$

\section{II}

Den engelske digter, Gerard Manley Hopkins (1844-89), arbejdede i sin digtning stædigt, næsten manisk med sprogets musikalske lyd. Hans digte, de bedste og fremmeligste af dem, er stærkt sammenbundne former karakteriseret ved traditionelle såvel som utraditionelle metriske og strofiske mønstre, mængden af alle typer rim og ikke mindst den særlige 'sprængte' rytme, som nok befordrer liniens ekspressive frihed, men er strengt funderet. Burgess, som jeg har citeret for nærværende teksts motto, sidestiller den sprængte fod med den musikalske takt, den hyppige brug af alliteration med sforzandi og dermed hele den lyriske linies bevægelse med en følge af akkorder (Burgess:62). Hopkins selv forsvarede sin digtning udfra dens klanglige aspekt, når den, af vennen Robert Bridges (den posthume udgiver) eksempelvis, blev kritiseret for "særhed " og „dunkelhed". I et brev til Bridges skriver han: 
"I opened and read some lines, as one commonly reads whether prose or verse, with the eyes, so to say, only; it struck me aghast with a kind of raw nakedness and unmitigated violence I was unprepared for: but take breath and read it with the ears, as I always wish to be read, and my verse becomes all right." 4

(Jeg slog op og læste nogle linier, som man almindeligvis læser, det være sig prosa eller digte, med øjnene, om man så må sige, alene; det forfærdede mig med en usleben nøgenhed og uformidlet voldsomhed, jeg ikke havde regnet med: men tag en indånding og læs med ørerne, som jeg altid ønsker at blive læst, og min digtning bliver, som den skal være).

"Take breath", tag en indånding, dvs. forbered dig, akkumulér den nødvendige energi, og læs så højt eller hørt indenad i én lang bevægelse med udåndingen. Dette er jo præcis sangerens eller blæserinstrumentalistens teknik og forudsætning for tilfredsstillende frasering. Hos Hopkins er digtet på siden i virkeligheden ikke meget andet end en opstilling, et partitur, der (som også det musikalske stykke) først realiseres i opførelsen. I „Author's Preface ${ }^{\prime \prime 5}$ trækker Hopkins selv paralleller til musikken. Sprængt rytme beskriver han som havende en naturlig affinitet med musik, idet det er den, der findes i remser, børnesange og folkelige viser, og foden sammenlignes igen, som hos Burgess, med den musikalske takt. De talrige markeringer, som omtales sammesteds, og som er indført i varierende grad i de forskellige manuskripter og udgaver - dvs. indryk, accenter, krøller, bindebuer etc., foruden tekst-opsætningens hele matrice-karakter - opfattes vel klarest som intet andet end anvisninger à la nodetegn, nødvendige angivelser for værkets rette gengivelse. Norman MacKenzie sammenligner Hopkins med ", a composer of music" og citerer ham: „[...] I must invent a notation throughout as in music [...]". Hopkins selv skriver: „[...] metrical marks are for the performer and such marks are proper in every art. "6 Således må forholdet mellem en visuel og en auditiv digtopfattelse medieres: På samme måde som partituret bestemt ikke er utilvirket råmateriale, men er et værk, færdig mulighed før realiseringen, er digtet parat til virkeliggørelsen i oplæsningen.

Læs nu forsøgsvis „The Windhover": 
I CAUGHT this morning morning's minion, kingdom of daylight's dauphin, dapple-dawn-drawn Falcon, in his riding

Of the rolling level underneath him steady air, and striding High there, how he rung upon the rein of a wimpling wing In his ecstasy! then off, off forth on swing,

As a skate's heel sweeps smooth on a bow-bend: the hurl and gliding

Rebuffed the big wind. My heart in hiding Stirred for a bird,-the achieve of, the mastery of the thing!

Brute beauty and valour and act, oh, air, pride, plume, here

Buckle! AND the fire that breaks from thee then, a billion Times told lovelier, more dangerous, $\mathrm{O}$ my chevalier!

No wonder of it: shéer plód makes plough down sillion Shine, and blue-bleak embers, ah my dear,

Fall, gall themselves, and gash gold-vermillion.

Her skal ingen oversættelse forsøges, blot en skitsering af digtets narrative linie og mening. Det lyriske jeg iagttager "denne morgen" (men jo ellers uden præcisering af tid og sted) falkens flugt og bevæges af det mesterskab som udfoldes. Det fører til en sammenligning med Kristi storhed („a billion/ Times told lovelier, more dangerous") og refleksion over selve sammenligningens mulighed, nemlig det, at denne storhedens figur kan iagttages i selv det jævneste og mindste. Dette er tilbagevendende hos Hopkins: det guddommelige, som forefindes overalt i verden, i naturen. ${ }^{7} \mathrm{Her}$ skal ikke analyseres eller tolkes i blot nogenlunde bredspektret omfang. At "The Windhover", som al Hopkins' digtning, kræver læserens yderste er vist tydeligt. Og det fremviser på bedste vis Hopkins' særheder: Hans egenhændige syntaks, ivrige brug af allitteration og excentriske billedsprog og apostrofering - hos hvilken anden religiøs digter (Hopkins var, må man huske, jesuit) forestiller man sig Kristus tiltalt med „O my chevalier!“ (og muligvis også ,"ah my dear")? Antydningen af homoerotik, "the classically queer" (Burgess:63), den umådelige sanselighed i det hele taget, krydser vel enhver ortodoksi. Men 
fremfor alt har vi her fuldt udfoldet den 'sprængte' rytme. Det er denne og det rytmiske i det hele taget, der er emnet i det følgende. Som sagt indledningsvis ser jeg rytmen som den vigtigste konstituent for det særligt lyrisk-musikalske, og hos Hopkins kan dette udfoldes $i$ en sådan grad, at jeg forsøgsvis vil bestemme hans digtning som endda egentlig lyrisk.

Når man i almindelighed taler om rytme i sprog, eller mere specifikt i en given tekst, er det gerne puls, man mener; dvs. en mere eller mindre mærkbar, fast markering manifesteret $i$ det sproglige stof, som det læses eller oplæses. Rytmen kan opfattes, opmåles og noteres på forskellig vis; den mest udbredte er naturligvis den metriske skandering i fødder. Det er stærkt debatteret, hvorvidt denne udmåling er nyttig eller overhovedet meningsfuld uden for de strenge formers digtning. Systemet som sådan er opstået fra klassisk digtning og baserer sig her på de enkelte stavelsers længde og er stavelsestællende. I modsætning til denne "romanske metrik" baserer den "germanske" variant sig på stavelsernes trykstyrke og trykantal. Det stavelsestællende resultat opgives i antal stavelser, eks. hendekasyllabel, det tryktællende $\mathrm{i}$ antal fødder, eks. pentameter. (Denne skelnen mellem romansk og germansk metrik er P. Aa Brandts.) ${ }^{8}$ Uenigheden om skanderingens brugbarhed opstår nu i og med digtningens større og større grad af frigørelse fra en hvilken som helst form for fast metrik, hvad enten den tæller stavelser eller tryk. Man benægter altså ikke pulsen eller rytmen men metrikkens mønstergyldighed. Det bliver heller ikke lettere af, at det germanske metrum afkodes intuitivt-heuristisk: „Man kan aldrig med sikkerhed udlede et metrisk mønster af sprogtrykfølgen i et [germansk] vers [...] Metrikkens manifestation i sprogstoffet vil derimod være den almene definition af rytme". Hvis læseren frembringer en "acceptabel frasering", har han "fundet digtets metrum" (m.k.), skriver Brandt videre (1994:90). Man ser nok, at skanderingen af romansk lyrik vil kunne afdække spændinger mellem stavelsernes metriske vægt og deres sproglige, akustiske vægt. Men hvordan forholder det sig for den germanske digtning, hvor metrum netop ikke foreligger, men så at sige skabes af læseren hen ad 
vejen? Her kan der strengt taget ikke tales om spændinger, eftersom sprogtryk læses som metrisk tryk. ${ }^{9}$

Hopkins holder sig såmænd ofte til metrisk konsistente former og lader de akustiske tryk, om man så må sige, glide af på metrikkens. Til andre tider arbejder han „kontrapunktisk" (i eks. "Thou art indeed just, Lord" og "God's Grandeur"), dvs. lader en fod eller flere løbe'mod' det faste metrum (hvorved opstår vel de Brandtske spændinger). Men mest spændende er han naturligvis, når han arbejder i 'sprængt' rytme (som i „The Windhover" og den berømte "Wreck of the Deutschland"), hvilket i en vis forstand vil sige konsekvent (og dermed ikke-fatteligt) kontrapunktisk. I. „Author's Preface“ giver han følgende definition:

"Sprung rhythm [...] is measured by the feet of from one to four syllables, regularly, and for particular effects any number of weak or slack syllables may be used. It has one stress, which falls on the only syllable, if there is only one, or, if there are more, then scanning as above, on the first, and so gives rise to four sorts of feet, a monosyllable and the so-called accentual Trochee, Dactyl, and the First Paeon." (1990(II):116)

(Sprængt rytme måles i fødder med fra én til fire stavelser, regelmæssigt, og for særlige effekter, må der benyttes et hvilkent som helst antal svage eller løse stavelser. Der er én betoning, som falder på den eneste stavelse, hvis der kun er én, eller, hvis der er flere, så skanderet som ovenfor på den første, hvilket giver anledning til fire slags fødder, en monosyllabel og den såkaldte trokæ, daktyl og pæon af første grad.)

Sprængt rytme bliver altså blot én rytme, Hopkins kalder den selv „logaoedisk" (blandet meter, fra det græske 'tale-sang'), hvorfor det også kan opfattes som fuldt ud kontrapunktisk: de omvendte fødder er ikke længere fattelige som sådan. Det får naturligvis konsekvenser for den rytmiske opfattelse i almindelighed og den metriske skandering i særdeleshed. For det første er antallet af fødder nominelt stærkt reduceret, for man har kun at gøre med fødder, hvis stærktryk ligger på første stavelse. ${ }^{10}$ For det andet vil fødderne sammenlignet være stærkt varierende af længde, heraf det 'sprængte'. Så sprængt rytme indbyder ikke længere til metrisk skandering, snarere tværtimod, for skanderingens princip modarbejdes af selve den sprængte rytmes ma- 
trice, der ikke længere ligner den metriske fod, men den musikalske takt. 'Taktering' indebærer, at man opfatter hvert stærktryk som begyndelsen af en ny takt eller fod; og at linierne løber 'igennem', uden stop, i en slags rytmisk enjambement. Hvad man $\mathrm{i}$ virkeligheden arbejder med er således pulsen, som ovenfor nævnt, og Hopkins' sprængte rytme viser sig at være Brandts germanske lyrik i sin essens og mest fuldkomne udtryk.

Eftersom pulsen er fast, vil den sprængte fod ligne den musikalske takt på den måde, at et ændret antal stavelser vil blive opvejet i disses indbyrdes styrkeforhold. Hopkins skriver:

"This practice is founded on the principle of equal strengths [...] so that wherever there is an accent or stress, there there [sic] is also so much unaccentuation, so to speak.“ (1990(I):119) Og: „In Sprung Rhythm, as in logaoedic rhyhm generally, the feet are assumed to be equally long or strong and their seeming inequality is made up by pause or stressing." (1990(II):116)

(Denne fremgansmåde baserer sig på princippet om ens styrke således, at hvor der optræder en accent eller betoning må der, om man så må sige, være ligeså meget ubetoning.) Og: (I sprængt rytme, som i logaoedisk rytme generelt, regnes fødderne for at være lige lange eller stærke, og deres tilsyneladende ulighed opvejes ved pause eller betoning.)

Princippet her kunne man kalde 'balanceret udmåling'. Hvis man ønsker den faste puls, må man afveje tryk mod stavelser eller, mere abstrakt, stoflig prægnans mod stoffets mængde. Dette er forskellen mellem logaoedisk, lyrisk om man vil, digtning og prosa: Pulsen som er fast underliggende det varierende antal inddelinger. Det minder jo slående om den musikalske takt.

Lad os vende tilbage til "The Windhover", de indledende linier, og sammenligne Hopkins' egen, sprængte skandering (I) med en traditionel, metrisk (II). 11

I

i ICAUGHT this IMORning I MORning's I MINion, I KINGdom of IDAYlight's IDAUphin dapple- IDAWN-drawn IFALcon, in his I RIding 
II

i CAUGHT I this MOR I ning MOR I ning's MI I nion, KING-

I dom of DAYlight's IDAUphin IDAPPle IDAWN-DRAWN IFALcon, in his I RIding

Det er vel tydeligt, hvor problematisk og upraktisk en traditionel metrisk skandering kan tage sig ud på en digtning, som ikke vil kendes ved den. Hvis det er skanderingens funktion at overskueliggøre og bringe klarhed, hvilket mønster kan man da udlede af fodfølgen jambe/jambe/jambe/jambe/anapest (ni-onKING)/pæon/trokæ/trokæ/spondæ/pæon/trokæ? Heroverfor viser (I) tydeligt distribueringen af stavelser i forhold til et fast antal stærktryk. (II) omgår selve den sprængte rytmes princip - én fod for ét stærktryk - og har derfor, fra pulsens synspunkt, ikke blot seks (hvilket allerede er én for meget) men syv fødder i anden linie (IDAWN- IDRAWN i stedet for IDAWNdrawn). Skanderet sprængt er hver strofe i "The Windhover" $i$ pentameter.

Begge skanderinger - takteringen og den metriske - giver nok acceptable læsninger, som ikke engang behøver at være så forskellige, når de høres, kun optakten afslører, om metrum i hovedsagen er trokæisk (I) eller jambisk (II). Men netop noteringen er vigtig for sprængt rytme, som den optræder midt i anden linie. Foden/takten „DAUphin dapple-“ bliver i den metriske skandering såvel overskåret som tildelt alt for meget tryk i forhold til linien som helhed. Det, der går tabt, er således den balancerede udmåling, pulsen, og den gennemløbende linie. Man kan med fordel banke pulsen (markeret ved stærktrykkene) og samtidig oplæse de to eksempler. Jeg tror, man vil opleve, hvordan pulsen i det andet eksempel enten må forkastes ved den sprængte fod eller beholdes med en markant nedsætning af oplæsningshastigheden til følge (hvilket i grunden er det samme): den enkelte fod har pludselig ikke stof nok.

I "The Wreck of the Deutschland" er hver strofe opbygget over samme matrice, det vil sige, at liniernes antal, deres meter, indryk og trykforhold er ens fra strofe til strofe, mens mængden af stof, stavelsernes antal og vægt er varierende. Forsøger man en 
traditionel skandering vil matrice-karakteren tildækkes medsamt al orden og struktur. Men skanderet sprængt, det vil sige takteret, slår den tydeligt igennem. Således må strofernes slutlinier skanderes som heksameter uafhængigt af stavelsesantal:

1. Strofe:

I Over a GAIN $\mathrm{i}$ | FEEL thy I FINger and I FIND I THEE

35. (sidste) strofe:

our IHEART'S charity's IHEARTH'S IFIRE, our ITHOUGHT'S chivalry's I THRONG's ILORD

Det ses og høres, hvordan rytmen i disse linier temmelig ligefremt lader sig oversætte til musikalsk notering: Vi har at gøre med to seks takters perioder i tre fjerdedels takt (denne dikteres af 1. strofen). En mulig notering af de to linier er dermed:

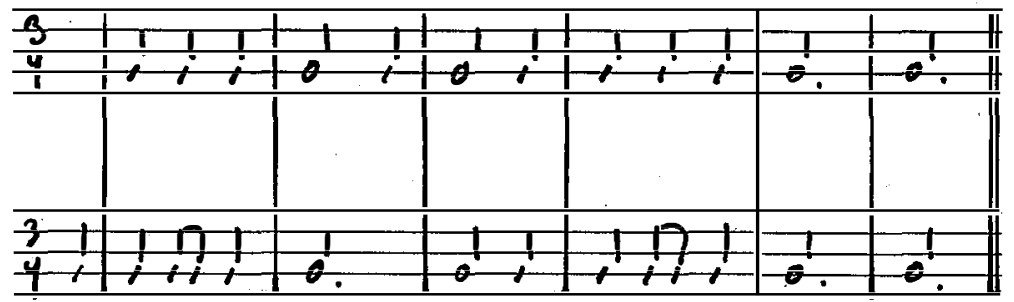

Kun i den anden af linierne, hvor stavelsesantallet i enkelte af fødderne er meget højt, benyttes ottendedele, den letteste nodeværdi her - igen en form for balanceret udmåling.

At forholde sig til takteringen vil sige at forholde sig til pulsen og dermed til selve logikken i sprængt rytme og dens nære affinitet med musikken. Per Aage Brandt skriver om metrik generelt: „Takt og fod er forbundne, idet en versefod elementært er et eller et par metrisk prægnant slag med omgivelser." (1994:91). For ham behøver fodens ' 1 ' ikke at have auditivt stærktryk, den er "taktuel prægnant" på samme måde, som musikken ikke nød- 
vendigvis "manifesterer det akustiske stærktryk" på '1'. Han nævner jazz og tango som eksempler, hvor man kan støde på en trykfølge som '1-2- 3-4', altså med akustisk stærktryk på andre dele end følgens positionelle markør (som er ' 1 ') og, kan man vel fortsætte, dens næste prioriterede slag (som i fire fjerdedelstakt er ' 3 ').

Men her tror jeg, med Hopkins som eksplicit eksempel og muligvis generelt, at parallellen til den musikalske rytmelogik viser sig problematisk. Den lyriske taktering har ikke nær så meget at holde sig til som den musiske, og derfor vil den altid hælde mod akustisk stærktryk på ' 1 ' og placere dette ' 1 ' i en sprogligt-logisk acceptabel position, hvorfor eventuelle forstavelser vil blive opfattet som optakt. I musikken er der så meget andet, der spiller ind; tangoen, for nu at tage et af Brandts eksempler, er en forudkendt musikalsk form, som blandt andet konstitueres ved den for os nordboere umage taktart, men vi kender netop til dette forhold før mødet med den (eller vi kender det ikke, men så er formen ikke tilgængelig som eksempel). Man kan hævde, at Alexandrineren eller sågar sonetten også kendes som former (i henholdsvis enkeltvers og digt) før mødet, men hermed udfører man en ulige analogi, for den særlige tango-taktfornemmelse måtte snarere svare til en, lad os sige, anapest-fornemmelse, hvilket er vel sludrende. En anapest indeholder specifikt tre stavelser (to svage + en stærk) men giver en lige taktfornemmelse: 1-2-3-4. En 'tango-takt' derimod ved vi er lige, men vi kan ikke på forhånd specificere noget node-antal. Omvendt kunne eksempelvis mestersangernes Bar-form (to Stollen + Abgesang, A-A-B) sammenlignes med en lyrisk form (sonetten byder sig til), men jo heller ikke med hverken noget meter eller nogen fod. For musikeren hjælper endvidere indtællingen straks på gled: taktens ' 1 ' er utvetydigt placeret trods eventuelle vildledende tryk, og taktfornemmelsen er heller ikke i ringe grad tonalt og harmonisk styret. ${ }^{12}$ Heroverfor har digtet i sprængt rytme intet andet end sprogligt- interne indikatorer. ${ }^{13}$ Stærktryk vil derfor sættes første mulige sted, og her vil foden blive opfattet som begyndt. 


\section{III}

Virker denne gennemgang af det rytmiske og - videre, per implikation, mener jeg - det musiske i digtningen en tand teknisk og ufølsomt konkret? Måske, og givet er det at intet af det foregående fortæller en tødel om digtets, eksempelvis "The Windhover"'s særlige kraft og skønhed. Der er skrevet og sagt meget vævende og besværgende om emnet - lyrikken og dens musik. Man hører stemmer. Man hører klang og tone og rytme og glemmer, i sin begejstring over disse termers lette, svævende og for litteraten metaforiske og uforpligtende karakter, hvad der reelt konstituerer vokabularet.

Lyrikken skal ikke frakendes en særlig status eller mulighed i forhold til den jævine prosa, men blot skal det præciseres, hvad der reelt er at tale om, når tanken falder på musikken, eller lyd i det hele taget, som skelnende forhold. Hvad ovenstående gennemgang vel også med al ønskelig tydelighed måtte vise er, at det gennemgående er den intense opmærksomhed på sproget som materiale, $i$ dets materialitet, som kendetegner det virkeligt lyriske. Naturligvis er sproget også for prosaisten mere end et simpelt medium, det er stadig råmateriale, som ikke tilvirkes på nogen simpel eller tilfældig måde. Lyrikken rejser sig alene ved hypostaseringen af dette arbejde. Den 'ved' ikke nødvendigvis mere end prosaen (priviligeringen af digtningen som sted for særlig indsigt i sprog, verden og væren), men den afprøver og udspænder sproget, 'taler nyt'. Man kan sige, at lyrikken til stadighed forholder sig til og/eller agerer sin egen væren lydfænomen, og det med størst tydelighed som udtalt, legemliggjort. Med Fafners formulering, "Der findes sprog, som ikke vil overses - eller overhøres. Det er lyrikken, der så at sige sætter transperansophævelsen i system" (Fafner:15), kan vi endvidere hævde en bredere opfattelse, hvor det lyriske kan tage mange former, og hvor det derfor snarere er et priviligerende end et priviligeret fænomen. Men skal vi acceptere talen om det musiske som lyrikkens forret, må jeg stadig insistere på rytmen som eneste reelle konstituent.

Ifølge Burgess, og så er vi full circle, deler Hopkins' digtning endnu et forhold med musikken, nemlig det, der drejer sig, ikke 
om materialet, men dets forvaltning: at hverken Hopkins' digtning eller musikken indeholder blot funktionelle elementer. Eller sagt på en anden måde: alt er udtryk. Fjern eller ret en tone i en melodi, og det er en anden melodi. Således også med en digtning, hvis kendetegn og ærinde er den stadige kondensering og optimering, og om hvilken man da ikke, om det overhovedet er muligt noget sted, kan tale om form og indhold som adskilte. Modstanden mod denne digtning, som kaldes sær, uklar, anstrengt og affekteret, kan derfor forskydes til en modstand mod selve det digteriske udtryk i sin helhed, når denne ikke uden videre lader sig opløse. Samme aggressivitet og uforståenhed, som ofte nok er blevet Hopkins til del, møder man hos læsere af Joyce. "Musicians both", skriver Burgess, "they were both concerned with bringing literature closer to music. [T]hey envied music its power of expression through rhythmic patterns, and also the complexity of meaning granted by that multilinear technique which is the glory of the music of the West." (Burgess:61-62). 


\section{Noter}

1. Burgess, "Gash Gold-vermillion", Urgent Copy. Literary studies, Penguin, Bungay 1973:62.

2. Disse overvejelser bygger delvist på G. Genette, Fiction and Diction, Cornell 1993:104ff. Genette skelner mellem ordets denotation, connotation, evocation/examplification og expression. Det sidste omhandler en overførsel af egenskaber: man spørger: hvad udtrykker ordet? Og svaret vil netop forholde sig metaforisk til spørgsmålet, som eksempelvis "gennemsigtighed" forholder sig til '[nuit]'.

3. Se P. A. Brandts definition af metrik: „Tællelig genkomst [...] Forskel bygger på identitet som bygger på metrik." I: „Hvad er Metrik?", Passage, nr. 16, 1994:88. Og J. Fafner om rimets morfologiske status: „[Stavelsesrimet har] udviklet sig til at fungere som struktursignal: det støtter og profilerer digtets metriske form." I: Digt og Form, Reitzel, Viborg 1989:63.

4. Hopkins, Selected Letters, Clarendon Press Oxford, Guildford 1990(I):124.

5. Hopkins, "Author's Preface on Rhythm", i: The Poetical Works of Gerard Manley Hopkins, ed. Norman H. MacKenzie, Clarendon Press Oxford, Guildford 1990(II):115- 117.

6. MacKenzie, "Introduction", i: Hopkins 1990(II), s. liii. Og Hopkins 1990(I):264.

7. Og Hopkins' idé om „instress“ og „inscape“, som er det guddommeliges pludselige tilsynekomst i det iagtagende, minder vel ikke så lidt om Joyce's „epiphanies". I sin Hopkins-læsning i The Linguistic Moment (Princeton N. J. 1987) får Hillis Miller, i en ellers spændende læsning, det guddommeliges tilsynekomst reduceret til et sprogligt og selvrefleksivt moment. Problemet i en sådan læsning er, at det fremlæste paradoks mellem udsagn og udsigelse tilsidesætter den ægte uophævelighed i det samlede udtryk og forviser disse udtrykkets to sider til hvert sit epistemologiske niveau. At udspaltningen måske slet ikke kan transcenderes i det analytiske sprog ses i vokabularets insisteren på dualismen, men rangeringen er problematisk i sig selv og burde ikke foretages så letsindigt som her.

8. Se: Brandt 1994:87-100. Naturligvis tæller romansk lyrik også fødder og germansk stavelser. Skelnenen angår udelukkende den tællemåde, som bestemmer skanderingens udfald.

9. Nu forholder moderne digtning sig da også gerne til, og låner fra, kendte former og skabeloner. Man kan naturligvis stadig redegøre for et digts eller en strofes metriske layout og derefter for dettes tradition, uregelmæssigheder osv. for så vidt der er fornuftig anledning dertil. Men hvor fører det os hen $i$ en forståelse af dette særlige digts rytme? Rytmen 
er stadig så ubegribelig for analytikeren som plottet for narratologen, når fabula kun kendes som rekonstruktion.

10. "This then is the essence of sprung rhythm: one stress makes one foot, no matter how many or few the syllables" (Hopkins 1990(I):120).

11. Se henholdvis Norton's Anthology of English Literature, (ed.) Abrams, USA 1968:1431, og The Penguin Dictionary of Literary Terms, (ed.) Cuddon, GB 1991:671.

12. Stort er ubehaget, når man lytter til et stykke musik og mister eller aldrig har tilegnet sig taktfornemmelsen. Hvad gør man så? Man leder indædt efter akustiske stærktryk, om de forekommer direkte eller opleves i pludselige men fattelige ændringer i tonehøjder, introducering af ny instrumentstemme eller andet. Sådan istandsættes taktfornemmelsen i musikken.

13. Og at tale om 'musikkens grammatik' er ligeså metaforisk (omend ikke ugyldigt) som at hævde, at musikken taler eller farverne synger. Metaforikken bygger på den generalisering, at grammatik blot er regler eller system, og at det er en given tonalitet også. Men man glemmer, at man laver sammenligningen, fordi den er nærliggende. Grammatikken minder blot mere om det dur/mol-tonale system eller dodekafonien end om færdselsreglerne. 
